\title{
Følges nye retningslinjer for hjerteinfarkt?
}

Faglige retningslinjer skal bidra til at alle pasienter tilbys behandling med vitenskapelig dokumentert effekt og er ett av verktøyene som skal sikre likhet uavhengig av bosted, alder og kjønn. Enkelte retningslinjer inneholder ikke bare anbefalinger om behandlingsvalg, de gir også tidsfrister. Dette gjelder for eksempel for akutt hjerteinfarkt, hvor fagmiljøet i Norge følger de europeiske retningslinjene. I 2011 og $2012 \mathrm{kom}$ det nye retningslinjer for behandling av henholdsvis hjerteinfarkt uten ST-heving (NSTEMI) (1) og hjerteinfarkt med ST-heving (STEMI) (2). For NSTEMI-pasientene er anbefalingen nå koronar angiografi og eventuelt perkutan koronar intervensjon (PCI) innen to timer fra første medisinske kontakt for høyrisikopasienter og innen 24 timer for majoriteten. Dette representerer en betydelig reduksjon i behandlingsvinduet fra tidligere anbefalinger som var henholdsvis innen 24 timer og innen 72 timer $(3,4)$.

Jortveit og medarbeidere publiserer i dette nummer av Tidsskriftet (5) en undersøkelse der de har sett på om pasienter med akutt hjerteinfarkt som ble innlagt ved Sørlandet sykehus Arendal i 2012 ble behandlet innenfor anbefalte tidsrammer. Sykehuset er PCIsenter for Agder-fylkene og Telemark. De fleste pasientene med STEMI ble innlagt direkte ved Sørlandet sykehus Arendal og fikk utført invasiv utredning og behandling innen anbefalte tidsfrister. For mange med hjerteinfarkt uten ST-elevasjon var derimot den revaskulariserende behandlingen forsinket. Median tid fra innleggelse ved annet sykehus til angiografi/PCI var 27,7 timer. $67,5 \%$ av disse pasientene fikk dermed ikke behandling innen tidsfristen i de europeiske retningslinjene.

Dataene er hentet ut av sykehusets registreringer i Norsk hjerteinfarktregister. Undersøkelsen er et eksempel på at et fagmedisinsk kvalitetsregister kan brukes til å hente ut behandlingsrelaterte kvalitetsmål. Det er prisverdig at Sørlandet sykehus Arendal som første norske sykehus rapporterer om etterlevelse av gjeldende retningslinjer. Fra 1.1. 2013 er Norsk hjerteinfarktregister tatt i bruk ved alle sykehus der man behandler akutt hjerteinfarkt. Deltakelse i registeret er lovpålagt. Det blir spennende å se resultatene også fra de andre sykehusene.

Jortveit og medarbeidere gjør flere interessante funn. Blålyskjeden for behandling av akutt hjerteinfarkt med ST-hevning representerte et pionerarbeid innen logistikk da den ble etablert for drøyt 15 år siden. Den ble raskt meget velfungerende. Men en god behandlingskjede hjelper lite dersom pasientene venter lenge med å varsle at de trenger hjelp. Median tid fra symptomdebut til innleggelse ved første sykehus ved STEMI var relativt kort i denne undersøkelsen og gjenspeiler at budskapet om viktigheten av tidlig varsling er nådd ut til befolkningen.

Etterlevelse av retningslinjene forutsetter ikke bare at de er kjent og implementert i fagmiljøet, men også at det er tilstrekkelig behandlingskapasitet. Sterke faglige anbefalinger om behandling innen stramme tidsrammer reduserer fleksibiliteten i helsevesenet. Det er overraskende at undersøkelsen ikke viste statistisk signifikant forskjell i tid fra innleggelse til koronar angiografi/PCI hos dem som ble innlagt i uken sammenliknet med dem som ble innlagt lørdag og søndag. Dette er ikke uventet når det gjelder STEMIpasientene, men det er et tankekors hva gjelder de mange NSTEMIpasientene som i stor grad må flyttes fra lokalsykehus til PCI-senter og tilbake. Når nasjonale data for 2013 foreligger, vil resultatene trolig ikke være like gode. Funnet indikerer en imponerende innsats av kolleger ved Sørlandet sykehus Arendal for å etterleve retningslinjene. Angiografi innen 24 timer fra første medisinske kontakt forutsetter reell 24-timersdrift ved koronarenheter, der søndager og helligdager i så fall vil bli nesten like travle som en vanlig hverdag. Det er vanskelig å se for seg dette uten en ikke ubetydelig økt helgebemanning både ved hjertemedisinske enheter og i prehospitale tjenester. Felles journal for samarbeidende sykehus hvor det er tilstrekkelig med et kort, oppdaterende notat ville vært til hjelp og vil kunne spare administrativt legearbeid ved inn- og utskrivning i denne type behandlingskjeder.

Forfatterne tar til orde for sterkere sentralisering til PCI-sentre for NSTEMI-pasienter der det er sterk klinisk mistanke om akutt hjerteinfarkt for revaskularisering innen to timer. Det er uvisst hvor mange det dreier seg om. Kartlegging av antallet vil være nødvendig både for dimensjonering av dagens behandlingssløyfer og i diskusjoner om desentralisering. De påpeker at ekkokardiografi i akuttmottaket vil kunne selektere dem som skal behandles raskt. Metoden anbefales som fast rutine i de nye europeiske retningslinjene for akutt koronarsyndrom uten ST-elevasjon (1). En norsk undersøkelse viste at ekkokardiografi i mottak av leger i tilstedevakt ved lokalsykehus ga god diagnostisk gevinst utover problemstillingen akutt hjerteinfarkt (6), men dette krever adekvat opplæring. Metoden vil være til viktig diagnostisk hjelp for pasienter som ikke blir sendt direkte til PCI-senter, men der rask behandling likevel er indisert. Revaskularisering innen to timer er imidlertid ikke forenlig med primær vurdering ved lokalsykehuset for dem det haster mest med. Beslutningen om hvor NSTEMI-pasienten skal innlegges, må tas ut fra prehospital informasjon og krever god kommunikasjon mellom sykehuslege og prehospitale tjenester.

\section{Cecilie Risøe}

risoe@mail.com

Cecilie Risøe (f. 1952) er overlege ved Kardiologisk avdeling, Oslo universitetssykehus, Rikshospitalet. Hun er leder i FaMe, sitter i styret for Norsk Cardiologisk Selskap og er medlem av rådgivningsgruppen i Norsk hjerteinfarktregister.

Forfatter har fylt ut ICMJE-skjemaet og oppgir ingen interessekonflikter.

\section{Litteratur}

1. Hamm CW, Bassand JP, Agewall S et al. ESC Guidelines for the management of acute coronary syndromes in patients presenting without persistent ST-segment elevation: The Task Force for the management of acute coronary syndromes (ACS) in patients presenting without persistent ST-segment elevation of the European Society of Cardiology (ESC). Eur Heart J 2011; 32: 2999-3054.

2. Steg PG, James SK, Atar D et al. ESC Guidelines for the management of acute myocardial infarction in patients presenting with ST-segment elevation. Eur Heart J 2012; 33: 2569-619

3. Wijns W, Kolh P. Danchin N et al. Guidelines on myocardial revascularization. Eur Heart J 2010; 31: 2501-55.

4. Bassand J-P, Hamm CW, Ardissino D et al. Guidelines for the diagnosis and treatment of non-ST-segment elevation acute coronary syndromes. Eur Heart J 2007; 28: 1598-660.

5. Jortveit J, Grenne B, Uchto $M$ et al. Følges retningslinjene for behandling av hjerteinfarkt? Tidsskr Nor Legeforen 2014; 134: 412-6.

6. Mjølstad OC, Andersen GN, Dalen $\mathrm{H}$ et al. Feasibility and reliability of point-ofcare pocket-size echocardiography performed by medical residents. Eur Heart J Cardiovasc Imaging 2013; 14: 1195-202. 